\title{
Revalidation of Bed Disinfectant Practices Followed By Farmers in the Rearing Of Silkworm Bombyx Mori L.
}

\author{
${ }^{1}$ H. C. Swathi, ${ }^{2}$ Vijayendra, M., ${ }^{3}$ Nagaraj, S. B. \\ Department Of Sericulture \\ ${ }^{1}$ College of Agriculture, Bangalore- 560065, Karnataka, India \\ ${ }^{2}$ College of Sericulture, Chintamani, Karnataka, India \\ ${ }^{3}$ College of Agriculture, Dharwad-580005, Karnataka, India
}

\begin{abstract}
The rearing was carried out at department of sericulture GKVK, UAS, Bangalore 2011-2012 to study the "Revalidation of Bed Disinfectant Practices followed by farmers for the rearing of Silkworm Bombyxmori $L$ ". Least larval duration was observed in daily application of hydrated lime powder at the rate of $5 \mathrm{~g} / \mathrm{sq} \mathrm{ft}+$ application of bundh powder after every moult (25.23 and 25.22 days, respectively) in both first and second rearing. In first rearing Larval mortality percentage, disease incidence of flacherie and muscardine was least in daily application of active lime powder at the rate of $3 \mathrm{~g} / \mathrm{sq} \mathrm{ft}+$ application of bundh powder after every moult $(10.16,10.04$ and $0.10 \%$, respectively). Cocoon weight, shell weight, pupal weight and shell ratio was maximum in daily application of hydrated lime powder at the rate of $5 \mathrm{~g} / \mathrm{sq} \mathrm{ft}+$ application of bundh powder after every moult $(1.96,0.330,1.63 \mathrm{~g}$ and $21.02 \%$, respectively) and effective rate of rearing, yield of cocoons and filament length was highest in daily application of active lime powder at the rate of $3 \mathrm{~g} / \mathrm{sq} \mathrm{ft}+$ application of bundh powder after every moult $(92.12 \%, 88.64 \mathrm{~g}$ and $758.5 \mathrm{~m}$, respectively). Larval mortality and flacherie and muscardine disease incidence was least in daily application of hydrated lime powder at the rate of $5 \mathrm{~g} / \mathrm{sq} \mathrm{ft}+$ application of bundh powder after every moult (10.67, 10.05 and $0.11 \%$, respectively). Effective rate of rearing, matured larval weight, cocoon weight, shell weight, pupal weight, shell ratio, yield of cocoons and filament length was maximum in daily application of hydrated lime powder at the rate of $5 \mathrm{~g} / \mathrm{sq} \mathrm{ft}+$ application of bundh powder after every moult $(92.13 \%, 2.67,1.98,0.34,1.64,21.08 \mathrm{~g}, 21.08 \%, 88.64 \mathrm{~g}$ and $758.5 \mathrm{~m}$ respectively) in second rearing.
\end{abstract}

Key words: Silkworm Bombyxmori L, Flacherie, Muscardine and Bed Disinfectant.

\section{Introduction}

Silk, the "Queen of Textiles", unchallenged so far by other fibres, is a nature's gift for human kind. India is one of the leading silk producing countries in world. At present India is the second largest silk producing country next only to China, producing all the four types of commercial silks namely mulberry, Eri, Tasar and Muga.

Sericulture provides gainful employment, economic development and improvement in the quality of life to the people in rural area and therefore it plays an important role in anti poverty programme and prevents migration of rural people to urban area in search of employment. To increase the silk production, there is a need to develop highly productive mulberry varieties and silkworm races which are tolerant to adverse climatic conditions and diseases.

Among the leading mulberry silk producing states Karnataka stands first, producing 44.84 per cent of the total production in India(Anonymous 2011). In Karnataka, the sericulture industry has been extended from traditional areas of Bangalore, Kolar, Tumkur, Mysore and Chamarajnagar to even non traditional areas.

Silkworms have been domesticated over centuries become very delicate and susceptible to diseases due to the infection by a number of pathogens. The infection by the pathogens and crop loses due to diseases is prevalent in all leading silk producing countries.

Silkworms are susceptible to a number of diseases caused by different infectious organisms (Doreswamyet al., 2004). The cocoon loss due to diseases in India is estimated to be about $15-20 \mathrm{~kg}$ per unit of 100 disease free layings which accounts for about 30 per cent of total loss (Selvakumaret al., 2002). Once the pathogen invades the silkworm, it is difficult to curb the pathogen. Hence, prevention of any disease is rather essential than attempting to control or cure. The pathogens including the virus can be prevented by cultural methods, physical and chemical agents.

The bed disinfectants are those substances which are applied on rearing bed to prevent contamination, further spread and multiplication of diseases causing germs.

To curb the diseases in silkworm rearing, different bed disinfectants and disinfection methods are evolved. Use of bed disinfectants gain a lot of importance in successful cocoon crop production. Various bed disinfectants viz., Vijetha, hydrated lime, Bundh powder, active lime, Captan, Dithane M-45, RKO, Ankush, 
VijethaSupplement, Reshamjyothi, Labex and formalin chaff are used in silkworm rearing. Among these most commonly used bed disinfectants by the farmers are active lime, hydrated lime, bundh powder, Vijetha which are being used in large quantities without any justification.

\section{Material Methods:}

Investigations were carried out to evaluate some chemicals as bed disinfectant against diseases of mulberry silkworm in the Department of Sericulture, University of Agricultural Sciences, GKVK, Bangalore, during 2011-2012.

Before the commencement of silkworm rearing, the rearing room and appliances were thoroughly cleaned and the floor was washed using 5 per cent bleaching powder solution. Then the whole room was disinfected with four per cent formalin at the rate of $1.5 \mathrm{ml} / \mathrm{m}^{2}$ (Dandinet al., 2003).

Popular multi $\mathrm{x}$ bivoltine cross breed $\mathrm{PMXCSR}_{2}$ was used in all the experiments. The layings were incubated at $25 \pm 1^{\circ} \mathrm{C}$ temperature and 75 to 80 per cent relative humidity.(Dandinet al., 2003).

The hatched out larvae were fed with chopped tender mulberry leaves. They were brushed onto the paraffin paper spread in a rearing tray. Wet foam rubber strips were kept all around the silkworm bed in the tray. Another paraffin sheet was used to cover the bed to maintain required relative humidity and temperature and to keep the leaves fresh and turgid. The larvae were fed three times a day with suitable quality leaves.

\section{Mulberry garden}

For rearings, $M_{5}$ mulberry variety grown in red soil with spacing of $90 \times 90 \mathrm{~cm}$ of the 10 years old plantation was used for the experiment.

\section{Experimental details}

The design used was Randomized Complete Block Design. Rearing was carried out in individual compartments assigned with treatment combination of Vijetha green, Hydrated lime, Active lime and Bundh powder bed disinfectants at various quantity at different times as follows

$\mathrm{T}_{1}$ : Application of bed disinfectant RKO (Vijetha) as per recommendation, control

$\mathrm{T}_{2}$ : Daily application of hydrated lime powder @ $5 \mathrm{~g} / \mathrm{sqft}$.

$\mathrm{T}_{3}$ : Daily application of active lime powder @3g/sqft.

$\mathrm{T}_{4}: \mathrm{T} 2+$ Application of bundh powder after every moult.

$\mathrm{T}_{5}: \mathrm{T}_{3}+$ Application ofbundh powder after every moult.

$\mathrm{T}_{6}: \mathrm{T}_{1}+$ Applicaion of hydrated lime @ $20 \mathrm{~g} / \mathrm{sqft}$ to the ripe stage.

$\mathrm{T}_{7}: \mathrm{T}_{1}+$ Application of active lime powder @ $10 \mathrm{~g} / \mathrm{sqft}$ to the ripe stage.

$\mathrm{T}_{8}: \mathrm{T}_{1}+\mathrm{T}_{2}$

$\mathrm{T}_{9}: \mathrm{T}_{1}+\mathrm{T}_{3}$

$\mathrm{T}_{10}$ : Absolute control.

\section{Manufacturers}

Bundh powder - Abubekar, Naiknalli, Kolar.

RKO - Sericare, Veticare division, Bangalore.

Hydrated lime powder - Sericare, Veticare, Purecare.

Active lime powder - Local market.

Each disinfectant was dusted on worms of three replications of 500 each.

These bed disinfectants were applied soon after bed cleaning, half an hour before giving the first feed. The larval duration, effective Rate of Rearing, larval mortality, matured larval weight, single cocoon weight, single shell weight, single pupal weight, shell ratio, yield of cocoons, single cocoon filament length were recorded.

\section{Schedule of feeding}

Chopped mulberry leaves were fed to the chawki worms and whole leaf feeding was followed for late age worms. The worms were fed three times a day at 8 a.m., 2 p.m. and 6 p.m.

\section{Observations recorded Larval duration} in days.

The time taken by the silkworm from hatching to spinning was taken as larval duration and expressed 


\section{Effective rate of rearing}

Effective rate of rearing (ERR) is the ratio of total number of cocoons formed to the total number of silkworms brushed. In each replication it was calculated to the number of worms brushed.

\section{Larval mortality}

The larval mortality was calculated by using the formula

No. of dead larvae

Larval mortality $(\%)=$ $\times 100$

Total no. of worms/treatment

\section{Fifth instar mature larval weight}

In each replication ten worms were weighed individually and average of the ten worms were calculated to get the accurate single mature larval weight.

\section{Single cocoon weight}

The cocoons were harvested on fifth day after spinning. In each replication ten cocoons at random were weighed. Individual cocoon weight was taken for 10 cocoons and average was calculated to complete the mean cocoon weight.

\section{Single shell weight}

In each replication, ten cocoons were cut, pupae and cast skin were separated and the cocoon shell weight was recorded and average was calculated to get the mean shell weight.

\section{Single pupal weight}

In each replication, ten pupae were separated from cut cocoons, weight was recorded and average was calculated to get the mean pupal weight.

\section{Shell ratio}

The cocoon shell ratio was calculated by using the following formula: shell weight $(\mathrm{g})$

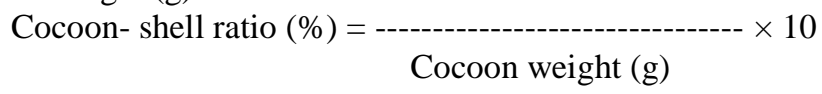

Pathogen load after the application and before the application of bed disinfectant particularly bacteria and fungi

Enumeration of spores in the fungal and bacterial suspension was done with the help of Neubauer's haemocytometer, which comprises of glass slides carrying calibrations in two replicates. No of spores $=$ Total spores counted $\mathrm{x}$ microscope magnification $\mathrm{x} 1000 \mathrm{x}$ dilution factor

\section{Disease incidence}

a) Type of disease incidence

b) Per cent of disease incidence

During rearing the infected worms and dead worms due to different diseases at each instar were recorded and expressed in per cent. The basis for symptoms of each disease were as stated by Govindanet al. (1998).

\section{Single cocoon filament length}

Ten randomly selected cocoons from each replication of every treatment were reeled separately to find out the filament length of the cocoon using epprouvette and it was determined by using the formula: $\mathrm{L}=\mathrm{R} \times 1.125$

Where,

$$
\begin{aligned}
& \mathrm{L}=\text { Filament length }(\mathrm{m}) \\
& \mathrm{R}=\text { Number of revolutions recorded by epprouvette } \\
& 1.125 \text { = Circumference of the reel of epprouvette }(\mathrm{m})
\end{aligned}
$$

\section{Statistical analysis and interpretation of data}

Data were analysed stastically for the test of significance using Fisher's method of analysis of variance as outlined by Sundarrajet al (1972). The level of significance of F- test was at 5 per cent. The interpretation of data was done using critical difference $(C D)$ values. 


\section{Result And Discussion:}

\section{Revalidation of the bed disinfectant practices of farmers in the laboratory}

Least larval duration was recorded in daily application of hydrated lime powder at the rate of $5 \mathrm{~g} / \mathrm{sq} \mathrm{ft}+$ application of bundh powder after every moult 25.23 in first and 25.22 days, respectively in second rearing followed by daily application of active lime powder at the rate of $3 \mathrm{~g} / \mathrm{sq} \mathrm{ft}+$ application of bundh powder after every moult ( 25.33 and 25.32 days, respectively) the least larval duration might have been attributed to the temperature and relative humidity as resulted by application of active lime powder and hydrated lime acting on the enzymatic mechanism in silkworm physiology. Similar results obtained by Rupusas and Gabriel (1976). The highest larval duration was recorded in control (26.70 and 26.81 days, respectively) followed by application of RKO as per recommendation + application of active lime powder at the rate of $10 \mathrm{~g} / \mathrm{sq} \mathrm{ft}$ to the ripe stage (26.24 and 26.29 days, respectively), application of RKO as per recommendation (26.17 and 26.19 days, respectively) in first and second rearing. This may be due to enhanced juvenile harmone level in the treatments. This is in conformity with Jagannatha (1996), Prasad (1999) and Patilet al. (1993).

The effective rate of rearing was highest in daily application of active lime powder at the rate of $3 \mathrm{~g} / \mathrm{sq}$ $\mathrm{ft}+$ application of bundh powder after every moult in first rearing and daily application of hydrated lime powder + application of bundh powder after every moult in second rearing (92.12 and $92.13 \%$, respectively). This might be due to the application of hydrated lime in high temperature as completed for high effective rate of rearing where as application of active lime in relatively low temperature in first rearing might have enhanced the effective rate of rearing. However daily application of hydrated lime powder at the rate of $5 \mathrm{~g} / \mathrm{sq} \mathrm{ft}+$ application of bundh powder after every moult recorded $90.33 \%$ and daily application of active lime powder at the rate of $5 \mathrm{~g} / \mathrm{sq} \mathrm{ft}+$ application of bundh powder after every moult recorded $90.33 \%$ in first and second rearing. The results are in concurrence with Balavenkatasubbaiahet al. (1989) and Subbaraoet al. (1992) have also recorded higher effective rate of rearing with hydrated lime during high temperature and active lime during low temperature this may be due to the reaction on hormonal condition in the physiology of silkworm. The least effective rate of rearing was recorded in control in both the rearing (76.24 and $76.31 \%$ respectively) indicating relatively high mortality due to non use of disinfectants. This also reinforces the effectiveness of active and hydrated lime complementing higher effective rate of rearing along with bundh powder. Chithraet al. (1975) stated that $30-40 \%$ crop loss was due to diseases which could be reduced by using effective bed disinfectants.

The maximum larval mortality was recorded in control batches (24.32 and $24.35 \%$, respectively) in first and second rearing. The least being 10.16 and $10.17 \%$ in daily application of active lime powder at the rate of $3 \mathrm{~g} / \mathrm{sq} \mathrm{ft}+$ application of bundh powder after every moult and daily application of hydrated lime powder at the of $5 \mathrm{~g} / \mathrm{sq} \mathrm{ft}+$ application of bundh powder after every moult respectively in first and second rearing. These results are in conformity with the farmers practicing the bundh powder in Kolar and Chikkaballapur districts. This is in conformity with dusting Kabinoran $1,2,3,4$ and $5 \mathrm{~g} / 0.1 \mathrm{~m} 2$ before giving first feed after every moult (Kasiviswanatan, 1976).

Mature larval weight was recorded highest in daily application of active lime powder at the rate of $3 \mathrm{~g} /$ $\mathrm{sq} \mathrm{ft}+$ application of bundh powder after every moult $(2.64 \mathrm{~g})$ and application of hydrated lime powder at the rate of $5 \mathrm{~g} / \mathrm{sq} \mathrm{ft}+$ application of bundh powder after every moult $(2.67 \mathrm{~g})$ in first and second rearing indicating the use of active lime in high temperature reducing matured larval weight $2.64 \mathrm{~g}$ and $2.67 \mathrm{~g}$ hydrated lime powder. However, the results indicate the use of hydrated lime with bundh powder in high temperature enhances matured larval weight. The similar results were also noticed by Shivashankar (2003). The control batches recorded least matured larval weight in both first and second rearing (2.10 and $2.11 \mathrm{~g}$, respectively) indicating the increased larval weight might be due to complementary effect of hormonal level in daily application of hydrated lime powder at the rate of $5 \mathrm{~g} / \mathrm{sq} \mathrm{ft}+$ application of bundh powder after every moult and daily application of active lime powder at the rate of $3 \mathrm{~g} / \mathrm{sq} \mathrm{ft}+$ application of bundh powder after every moult treated silkworms.

The application of hydrated lime powder at the rate of $5 \mathrm{~g} / \mathrm{sq} \mathrm{ft}+$ application of bundh powder after every moult is known to increase cocoon weight 1.96 and $1.98 \mathrm{~g}$, shell weight 0.33 and $0.34 \mathrm{~g}$, pupal weight 1.63 and $1.64 \mathrm{~g}$, shell ratio $21.02 \%$ and $21.08 \%$, respectively in first and second rearing indicating the positive effect of hydrated lime and bundh powder on enhanced cocoon parameters. Similar results were also found by the treatment of hydrated lime by Shivashankar (2003) and Balavenkatasubbaiahet al. (1989). In all the cases absolute control recorded least values in cocoon weight $1.52 \mathrm{~g}$, shell weight 0.23 and 0.22 , pupal weight 1.29 and $1.30 \mathrm{~g}$, shell ratio 16.21 and $16.22 \%$ respectively in first and second rearing where no application of lime or disinfectants. This possibly reveals the impact of lime and disinfectants moves of bundh powder having hormonal effect on silkworm.

The yield of cocoons were highest in daily application of active lime powder at the rate of $3 \mathrm{~g} / \mathrm{sq} \mathrm{ft}$ +application of bundh powder after every moult $(88.64 \mathrm{~g} / 50$ cocoons) and $88.66 \mathrm{~g} / 50$ cocoons in first and second rearing. The second highest values are recorded in daily application of hydrated lime powder at the rate of $5 \mathrm{~g} / \mathrm{sq} \mathrm{ft}+$ application of bundh powder after every moult (88.23g) and daily application of active lime 
powder at the rate of $3 \mathrm{~g} / \mathrm{sq} \mathrm{ft}+$ application of bundh powder after every moult $(88.24 \mathrm{~g} / \mathrm{sq} \mathrm{ft})$ in first and second rearing respectively. The least being in control $56.23 \mathrm{~g}$ in both the rearings. This is in conformity with Samson et al. (1987) stated that RKO reduces disease incidence compared to control batches and consequent improvement in yield.

Filament length was recorded more in daily application of active lime powder at the rate of $3 \mathrm{~g} / \mathrm{sq} \mathrm{ft}+$ application of bundh powder after every moult $(758.5 \mathrm{~m})$ and in daily application of hydrated lime powder at the rate of $5 \mathrm{~g} / \mathrm{sq} \mathrm{ft}+$ application of bundh powder after every moult $(768.5 \mathrm{~m})$ respectively in first and second rearing indicating highest filament length followed by the least in absolute control $(679.5$ and $679.4 \mathrm{~m}$, respectively) similar results were also reported by Narasimhannaet al (1975) and Jagannatha (1996) where significantly higher filament length recorded by applying formalin chaff and Lime +dithane M-45 application.

The pathogen load of Bacteria werenill in the beginning. However, the study revealed that the daily application of active lime powder at the rate of $3 \mathrm{~g} / \mathrm{sq} \mathrm{ft}+$ application of bundh powder after every moult and daily application of hydrated lime powder at the rate of $5 \mathrm{~g} / \mathrm{sq} \mathrm{ft}+$ application of bundh powder after every moult has reduced the pathogen load in the course of rearing being $\left(2.8 \times 10^{-6}, 2.4 \times 10^{-7}\right.$ and $2.7 \times 10^{-6}, 2.2 \times 10^{-7}$, respectively) indicating the suppression of growth of bacteria. In the fungal pathogen load was nill in the beginning followed by the least multiplication in daily application of active lime powder at the rate of $3 \mathrm{~g} / \mathrm{sq} \mathrm{ft}$ + application of bundh powder after every moult $\left(2.2 \times 10^{-6}\right.$ and $2.1 \times 10^{-7}$, respectively) $\left(2.1 \times 10^{-6}\right.$ and $\left.2.0 \times 10^{-7}\right)$ in both the rearings. Revealed the suppression of growth of bacteria and fungus leading to low mortality and high effective rate of rearing. This study implies the effective role of lime and bundh powder in successful suppression of the pathogen load. Similar studies were also conducted by Patilet al 1998 reporting that Suchi, a liquid formulation has effectively curbed the pathogen load. Similar results were also noticed McDonnell and Russel in 1999 a wide variety of chemical agents (biocides) are found as antiseptics and disinfectants over hundreds of years including alcohols, phenols, iodine and chlorine.

The disease incidence recorded was low in daily application of active lime powder at the rate of $3 \mathrm{~g} / \mathrm{sq}$ $\mathrm{ft}+$ application of bundh powder after every moult (10.04\% flacherie and $0.10 \%$ muscardine) in first rearing. However, second rearing daily application of hydrated lime powder at the rate of $5 \mathrm{~g} / \mathrm{sq} \mathrm{ft}+$ application of bundh powder after every moult (10.05\% flacherie and $0.11 \%$ muscardine) and maximum disease incidence was noticed in absolute control (22.56\% flacherie, $1.75 \%$ muscardine and $22.54 \%$ flacherie, $1.74 \%$ muscardine, respectively) in first and second rearing. Revealing effective control flacherie and muscardine in hydrated lime, active lime in combination with bundh powder. The results are in concurrence with Subbaraoet al. (1992) where the incidence of muscardine was least when treated with captan and dithane M-45 indicating the possible inclusion of fungicides.

\section{References}

[1] Anonymous, 2011, Highlights of Central Silk Board's activities. Ann. Rep. (2010-2011), CSB, Bangalore.

[2] Balavenkatasubbaiah, M., Sharma, S.D., Baig, M., Singh, B.D., Venkatareddy, S. and Noamani, M.K.R., 1989, Role of disinfection of rearing appliances and sun-light exposure on the inactivation of disease causing pathogen of silkworm, Bombyxmori L. Indian J. Seric., 28(2): 200-205.

[3] Chithra, C., Karanth, N.G.K. and Vasanthrajan, V.N., 1975, Disease of mulberry silkworm, BombyxmoriL. J. Sci. Ind Res.,34: 386401.

[4] Dandin, S.B., Jayaswal, J. and Giridhar, K., 2003, Handbook of Sericulture Technologies. CSB, Bangalore, p. 287.

[5] Doreswamy, C., Govindan, R., Devaiah, M.C. and Muniswamappa, M.V., 2004, Deterioration of cocoon traits of silkworm, BombyxmoriL. by the synergistic infection with late larval flacherie pathogens. Karnataka J. Agric. Sci., 17: $345-348$.

[6] Govindan, R., Narayanaswamy, T.K. and Devaiah, M.C., 1998, Priciples of Silkworm pathology. Seri Scientific publishers, Bangalore, p.420.

[7] Jagannatha,K.R., 1996, Evaluation of commercial germicides for their utility as disinfectants in silkworm rearing. M.Sc. (Agri.) Thesis, UAS, Bangalore, p. 136.

[8] Kasiviswanathan, K., 1976, How Japan fights muscardine, Indian Silk,14(11):15-19.

[9] McDonnell, G. and Russel, 1999, Antiseptics and disinfectants : Activity, action and resistance. Clin. Microbial, Rev., 12: 147-179.

[10] Narasimhanna, M. N., Samson, M.V. and Baig, M., 1975, Studies on the control of white muscardine disease of silkworm. Ann. Rep. CSR\&TI, Mysore, p.106-111.

[11] Patil, C.S., Sharadamma, P. and Venkatesh, C.M., 1998, Suchi: A new disinfectant. Indian Silk,37 (4): $17-18$

[12] Prasad, N.R., 1999, Lime and its application in silkworm disease management. Indian Silk, 11:12-13.

[13] Rupusas, H.R. and Gabrial, B.P., 1976, Suitable temperature humidity and larval density in the rearing of Bombyxmori L. The Philippines Agriculturalist, 60(4): 130-138.

[14] Samson, M.V., Baig, M. and Jolly, M.S., 1987, ReshamKeetOushad- a prospective bed disinfectant against Grasserie and Muscardine. Indian Silk,25(1):16-18.

[15] Selvakumar, T., Nataraju, B., Balavenkatasubbaiah, M., Sivaprasad, V. and Baig, M., 2002, A report on the prevalence of silkw orm diseases and estimated crop loss. In: Advances in Indian Sericulture Research, CSRTI, Mysore, pp. 357-357.

[16] Shivashankar, 2003,Effective use of lime and bleaching powder as surface disinfectants for mulberry silkworm cocoon crop success. M.Sc. (Seri.) Thesis, UAS, Bangalore. P.45.

[17] Subbarao, G., Chandra, A.K. and Battacharya, J., 1992, Effect of bleaching powder and lime against grasserie and muscardine diseases of the silkworm, Bombyxmori L. Indian J. Seric.,31(1): 37-40.

[18] Sundarraj, N., Nagaraju, S., Venkataramu, M.N. and Jagannath, M.K., 1972, Design and Analysis of Field Experiments. Directorate of Research, UAS, Bangalore, p.139. 
Table 1. Effect of different combinations of bed disinfectant on larval duration, ERR, larval mortality and mature larval weight in silkworm hybrid PMXCSR

\begin{tabular}{|c|c|c|c|c|c|c|c|c|}
\hline \multirow{2}{*}{ Treatments } & \multicolumn{2}{|c|}{$\begin{array}{l}\text { Larval duration } \\
\text { (days) }\end{array}$} & \multicolumn{2}{|c|}{ ERR (\%) } & \multicolumn{2}{|c|}{ Larval mortality (\%) } & \multicolumn{2}{|c|}{ Mature larval weight $(g)$} \\
\hline & $\begin{array}{c}\text { First } \\
\text { rearing }\end{array}$ & $\begin{array}{l}\text { Second } \\
\text { rearing }\end{array}$ & $\begin{array}{c}\text { First } \\
\text { rearing }\end{array}$ & $\begin{array}{l}\text { Second } \\
\text { rearing }\end{array}$ & $\begin{array}{c}\text { First } \\
\text { rearing }\end{array}$ & $\begin{array}{l}\text { Second } \\
\text { rearing }\end{array}$ & $\begin{array}{c}\text { First } \\
\text { rearing }\end{array}$ & $\begin{array}{l}\text { Second } \\
\text { rearing }\end{array}$ \\
\hline $\mathrm{T} 1$ & 26.17 & 26.19 & 82.25 & 82.24 & 18.11 & 18.15 & 2.15 & 2.18 \\
\hline $\mathrm{T} 2$ & 25.63 & 25.61 & 88.51 & 88.54 & 12.24 & 12.25 & 2.53 & 2.55 \\
\hline $\mathrm{T} 3$ & 25.37 & 25.36 & 86.31 & 86.35 & 14.50 & 14.55 & 2.34 & 2.33 \\
\hline $\mathrm{T} 4$ & 25.23 & 25.22 & 90.33 & 92.13 & 10.61 & 10.17 & 2.61 & 2.67 \\
\hline T5 & 25.33 & 25.32 & 92.12 & 90.35 & 10.16 & 10.67 & 2.64 & 2.61 \\
\hline T6 & 26.14 & 26.17 & 82.50 & 82.52 & 18.42 & 18.44 & 2.23 & 2.25 \\
\hline $\mathrm{T} 7$ & 26.24 & 26.29 & 84.64 & 84.66 & 16.53 & 16.52 & 2.18 & 2.18 \\
\hline $\mathrm{T} 8$ & 25.73 & 25.76 & 88.57 & 88.61 & 12.15 & 12.13 & 2.47 & 2.47 \\
\hline T9 & 25.51 & 25.62 & 89.10 & 89.12 & 10.90 & 10.92 & 2.50 & 2.52 \\
\hline $\mathrm{T} 10$ & 26.70 & 26.81 & 76.24 & 76.31 & 24.32 & 24.35 & 2.10 & 2.11 \\
\hline SEm+ & 0.01 & 0.01 & 0.03 & 0.03 & 0.006 & 0.008 & 0.008 & 0.006 \\
\hline $\mathrm{C} \mathrm{D}$ at $5 \%$ & 0.06 & 0.03 & 0.09 & 0.11 & 0.07 & 0.02 & 0.024 & 0.01 \\
\hline
\end{tabular}

T1: Application of bed disinfectant RKO (Vijetha) as per recommendation ,control

T2 : Daily application of hydrated lime powder@ 5g/sqft.

T3 : Daily application of active lime powder @ 3g/sqft.

T4: T2+Application of bundh powder after every moult.

$\mathrm{T} 5: \mathrm{T}_{3}+$ Application of bundhpowder .

T6: T1+Applicaion of hydrated lime @ 20g/sqft to the ripe stage.

T7: T1+Application of active lime powder@ 10g/sqft to the ripe stage.

$\mathrm{T} 8: \mathrm{T} 1+\mathrm{T}_{2}$

$\mathrm{T} 9: \mathrm{T} 1+\mathrm{T}_{3}$

T10: Absolute control

Table 2. Effect of different combinations of bed disinfectants on the incidence of diseases and pathogen load after the application of bed disinfectants in silkworm hybrid PMXCSR2

\begin{tabular}{|c|c|c|c|c|c|c|c|c|}
\hline \multirow{2}{*}{ Treatments } & \multicolumn{2}{|c|}{$\begin{array}{c}\text { Larval duration } \\
\text { (days) }\end{array}$} & \multicolumn{2}{c|}{ ERR (\%) } & \multicolumn{2}{c|}{ Larval mortality (\%) } & \multicolumn{2}{c|}{ Mature larval weight(g) } \\
\cline { 2 - 9 } & $\begin{array}{c}\text { First } \\
\text { rearing }\end{array}$ & $\begin{array}{c}\text { Second } \\
\text { rearing }\end{array}$ & $\begin{array}{c}\text { First } \\
\text { rearing }\end{array}$ & $\begin{array}{c}\text { Second } \\
\text { rearing }\end{array}$ & $\begin{array}{c}\text { First } \\
\text { rearing }\end{array}$ & $\begin{array}{c}\text { Second } \\
\text { rearing }\end{array}$ & $\begin{array}{c}\text { First } \\
\text { rearing }\end{array}$ & $\begin{array}{c}\text { Second } \\
\text { rearing }\end{array}$ \\
\hline T1 & 26.17 & 26.19 & 82.25 & 82.24 & 18.11 & 18.15 & 2.15 & 2.18 \\
\hline T2 & 25.63 & 25.61 & 88.51 & 88.54 & 12.24 & 12.25 & 2.53 & 2.55 \\
\hline T3 & 25.37 & 25.36 & 86.31 & 86.35 & 14.50 & 14.55 & 2.34 & 2.33 \\
\hline T4 & 25.23 & 25.22 & 90.33 & 92.13 & 10.61 & 10.17 & 2.61 & 2.67 \\
\hline T5 & 25.33 & 25.32 & 92.12 & 90.35 & 10.16 & 10.67 & 2.64 & 2.61 \\
\hline T6 & 26.14 & 26.17 & 82.50 & 82.52 & 18.42 & 18.44 & 2.23 & 2.25 \\
\hline T7 & 26.24 & 26.29 & 84.64 & 84.66 & 16.53 & 16.52 & 2.18 & 2.18 \\
\hline T8 & 25.73 & 25.76 & 88.57 & 88.61 & 12.15 & 12.13 & 2.47 & 2.47 \\
\hline T9 & 25.51 & 25.62 & 89.10 & 89.12 & 10.90 & 10.92 & 2.50 & 2.52 \\
\hline T10 & 26.70 & 26.81 & 76.24 & 76.31 & 24.32 & 24.35 & 2.10 & 2.11 \\
\hline SEm + & 0.01 & 0.01 & 0.03 & 0.03 & 0.006 & 0.008 & 0.008 & 0.006 \\
\hline C D at 5\% & 0.06 & 0.03 & 0.09 & 0.11 & 0.07 & 0.02 & 0.024 & 0.01 \\
\hline
\end{tabular}

T1: Application of bed disinfectant RKO (Vijetha) as per recommendation, control

T2 : Daily application of hydrated lime powder@ 5g/sqft.

T3 : Daily application of active lime powder @ 3g/sqft.

T4: T2+Application of bundh powder after every moult.

$\mathrm{T}$ 5: $\mathrm{T}_{3}+$ Application of bundhpowder .

T6: T1+Applicaion of hydrated lime @ 20g/sqft to the ripe stage.

T7: T1+Application of active lime powder@ 10g/sqft to the ripe stage.

$\mathrm{T} 8: \mathrm{T} 1+\mathrm{T}_{2}$

$\mathrm{T} 9: \mathrm{T} 1+\mathrm{T}_{3}$

T10: Absolute control 
Revalidation of Bed Disinfectant Practices Followed By Farmers in the Rearing Of Silkworm Bombyx

Table 3. Effect of different combinations of bed disinfectant on economic characters of silkworm hybrid PMXCSR $_{2}$

\begin{tabular}{|c|c|c|c|c|c|c|c|c|c|c|c|c|}
\hline \multirow[b]{2}{*}{$\begin{array}{l}\text { Treatment } \\
\text { s }\end{array}$} & \multicolumn{2}{|c|}{$\begin{array}{l}\text { Cocoon weight } \\
\text { (g) }\end{array}$} & \multicolumn{2}{|c|}{ Shell weight (g) } & \multicolumn{2}{|c|}{ Pupal weight (g) } & \multicolumn{2}{|c|}{ Shell ratio $(\%)$} & \multicolumn{2}{|c|}{$\begin{array}{c}\text { Yield of cocoons } \\
(\mathrm{g})\end{array}$} & \multicolumn{2}{|c|}{$\begin{array}{c}\text { Filament length } \\
(\mathrm{m})\end{array}$} \\
\hline & $\begin{array}{c}\text { First } \\
\text { rearin } \\
\mathrm{g}\end{array}$ & $\begin{array}{c}\text { Secon } \\
d \\
\text { rearin } \\
\mathrm{g}\end{array}$ & $\begin{array}{l}\text { First } \\
\text { rearin } \\
\quad \mathbf{g}\end{array}$ & $\begin{array}{c}\text { Secon } \\
\mathbf{d} \\
\text { rearin } \\
\mathrm{g} \\
\end{array}$ & $\begin{array}{l}\text { First } \\
\text { rearin } \\
\quad \mathbf{g}\end{array}$ & $\begin{array}{c}\text { Secon } \\
\mathbf{d} \\
\text { rearin } \\
\mathrm{g} \\
\end{array}$ & $\begin{array}{l}\text { First } \\
\text { rearin } \\
\quad \mathbf{g}\end{array}$ & $\begin{array}{c}\text { Secon } \\
\mathbf{d} \\
\text { rearin } \\
\mathrm{g} \\
\end{array}$ & $\begin{array}{c}\text { First } \\
\text { rearin } \\
\mathrm{g}\end{array}$ & $\begin{array}{l}\text { Secon } \\
\mathbf{d} \\
\text { rearin } \\
\mathrm{g} \\
\end{array}$ & $\begin{array}{l}\text { First } \\
\text { rearin } \\
\quad \mathbf{g}\end{array}$ & $\begin{array}{c}\text { Secon } \\
\mathbf{d} \\
\text { rearin } \\
\mathrm{g} \\
\end{array}$ \\
\hline $\mathrm{T} 1$ & 1.59 & 1.62 & 0.283 & 0.29 & 1.31 & 1.33 & 16.29 & 16.32 & 66.35 & 66.37 & 718.6 & 718.6 \\
\hline $\mathrm{T} 2$ & 1.86 & 1.83 & 0.323 & 0.28 & 1.53 & 1.55 & 19.87 & 19.83 & 83.24 & 83.26 & 722.2 & 722.2 \\
\hline $\mathrm{T} 3$ & 1.91 & 1.90 & 0.320 & 0.32 & 1.59 & 1.58 & 18.46 & 18.47 & 84.47 & 84.51 & 739.2 & 739.2 \\
\hline $\mathrm{T} 4$ & 1.96 & 1.98 & 0.330 & 0.34 & 1.63 & 1.64 & 21.02 & 21.08 & 88.23 & 88.66 & 749.2 & 758.5 \\
\hline T5 & 1.95 & 1.95 & 0.326 & 0.32 & 1.62 & 1.63 & 20.24 & 20.28 & 88.64 & 88.24 & 758.5 & 749.2 \\
\hline T6 & 1.66 & 1.65 & 0.313 & 0.31 & 1.34 & 1.33 & 17.62 & 17.63 & 69.71 & 69.72 & 724.2 & 715.4 \\
\hline T7 & 1.62 & 1.59 & 0.306 & 0.28 & 1.32 & 1.31 & 16.35 & 16.37 & 67.51 & 67.52 & 700.5 & 700.5 \\
\hline T8 & 1.76 & 1.76 & 0.316 & 0.29 & 1.45 & 1.47 & 19.31 & 19.36 & 78.31 & 78.33 & 724.2 & 724.2 \\
\hline T9 & 1.80 & 1.82 & 0.310 & 0.30 & 1.49 & 1.51 & 18.85 & 18.85 & 81.89 & 81.85 & 735.4 & 735.4 \\
\hline $\mathrm{T} 10$ & 1.52 & 1.52 & 0.230 & 0.22 & 1.29 & 1.30 & 16.22 & 16.21 & 56.25 & 56.23 & 679.5 & 679.4 \\
\hline SEm+ & 0.007 & 0.007 & 0.006 & 0.007 & 0.008 & 0.006 & 0.01 & 0.007 & 0.01 & 0.18 & 0.26 & 0.31 \\
\hline $\mathrm{CD}$ at $5 \%$ & 0.02 & 0.02 & 0.02 & 0.02 & 0.02 & 0.02 & 0.03 & 0.02 & 0.03 & 0.54 & 0.79 & 0.95 \\
\hline
\end{tabular}

T1: Application of bed disinfectant RKO (Vijetha) as per recommendation ,control

T2 : Daily application of hydrated lime powder@ 5g/sqft.

T3 : Daily application of active lime powder @ 3g/sqft.

T4: T2+Application of bundh powder after every moult.

$\mathrm{T} 5: \mathrm{T}_{3}+$ Application of bundhpowder .

T6: T1+Applicaion of hydrated lime @ 20g/sqft to the ripe stage.

T7: T1+Application of active lime powder@10g/sqft to the ripe stage.

$\mathrm{T} 8: \mathrm{T} 1+\mathrm{T}_{2}$

$\mathrm{T} 9: \mathrm{T} 1+\mathrm{T}_{3}$

T10: Absolute control 